\title{
TAENIA ANTIGENS DETECTION IN THE CEREBROSPINAL FLUID OF PATIENTS WITH NEUROCYSTICERCOSIS AND ITS RELATIONSHIP WITH CLINICAL ACTIVITY OF THE DISEASE
}

\author{
Ronaldo Abraham ${ }^{1}$, Alessandra Xavier Pardini' ${ }^{2}$, Adelaide José Vaz ${ }^{3}$, \\ José Antonio Livramento ${ }^{4}$, Luís dos Ramos Machado ${ }^{5}$
}

\begin{abstract}
Objective: (1) To determine the concentration of Taenia antigens in the cerebrospinal fluid (CSF) of patients with neurocysticercosis (NC); (2) to establish its relationship with clinical activity of the disease and with classical variables of CSF. Method: A CSF examination was performed in one sample from 36 patients with definitive diagnosis of NC, including: quantitative and cytomorphological study, biochemical tests, immunological reactions for cysticercosis and Taenia antigens. The antibodies for antigens detection were obtained from the larval form of Taenia crassiceps, ORF strain. After intraperitoneal passage through female mice, a group of rabbits was immunized with vesicular fluid antigens. Results: The Taenia antigen was detected in CSF from 17 patients (47.2\%), especially in those patients with epileptic symptoms in the last 12 months. Conclusion: Taenia antigens presence in CSF have significant relationship with clinically active forms of NC, being a more sensitive marker than the classic eosinophil presence.
\end{abstract}

KEY WORDS: neurocysticercosis, Taenia antigens, neurocysticercosis clinical activity.

\begin{abstract}
Dosagem de antígenos de Taenia no líquido cefalorraquidiano em pacientes com neurocisticercose e sua relação com a atividade clínica da doença

RESUMO - Objetivo: (1) Determinar a concentração de antígenos de Taenia no líquido cefalorraquidiano (LCR) em doentes com neurocisticercose; (2) estudar sua relação com a atividade clínica da doença e com as variáveis clássicas do LCR. Método: Em 36 pacientes com diagnóstico definido de neurocisticercose foi realizado exame do LCR, com estudo citológico e citomorfológico, exame bioquímico, reações imunológicas para cisticercose e detecção de antígenos de Taenia. Os anticorpos para detecção desses antígenos foram obtidos a partir da forma larvar da Taenia crassiceps, cepa ORF. Após a inoculação e proliferação intraperitoneal dessa forma larvária em ratas, foi imunizado um grupo de coelhos com seu líquido vesicular. Resultados: Em 17 pacientes $(47,2 \%)$ foi detectado antígeno de Taenia, especialmente naqueles com manifestação epiléptica nos últimos 12 meses. Conclusão: A detecção de antígeno de Taenia guarda relação significativa com a vigência de formas clinicamente ativas, sendo, nestas formas, marcador mais sensível que a eosinofilorraquia.
\end{abstract}

PALAVRAS-CHAVE: neurocisticercose, antígenos de Taenia, atividade clínica da neurocisticercose.

Neurocysticercosis (NC) is defined as the infection of the central nervous system caused by Cysticercus cellulosae, the larval stage of Taenia solium ${ }^{1,2}$ acquired mainly by ingesting eggs of Taenia solium hidden in food, especially vegetables and fruits. Despite being considered an eradicable disease ${ }^{3}$, it remains a public health challenge for most developing countries ${ }^{4}$, representing an important fac- tor in the genesis of epilepsy ${ }^{5,6}$. NC probably explains the high tropical countries ranges of active epilepsy, reaching almost twice the level of developed countries ${ }^{7}$. In the last two decades NC became an emerging problem in the United States of America, where thousands of cases per year are now being reported ${ }^{8,9}$. In Southern California NC accounts for about $2 \%$ of neurological and neurosur-

\footnotetext{
University of Taubaté, São Paulo SP, Brazil (UT), Faculty of the Medicine of the University of São Paulo, São Paulo SP, Brazil (FMUSP) and Biomedical Science Institute of the University of São Paulo São Paulo SP, Brazil (BSI): ${ }^{1} \mathrm{MD}$, Master in Neurology, Medicine Department, UT; ${ }^{2}$ Biochemistry, Phd, Department of Immunology, BSI; ${ }^{3}$ Biochemistry, Department of Immunology, Phd, BSI; ${ }^{4} \mathrm{MD}$, Phd, Department of Neurology, FMUSP; ${ }^{5}$ MD, Phd, Department of Neurology, FMUSP.
}

Received 4 March 2004, received in final form 4 May 2004. Accepted 9 June 2004.

Dr. Ronaldo Abraham - Rua Dr. Souza Alves 364 - 12020-030 Taubaté SP - Brasil. E-mail: nrabraham@uol.com.br 
gical admissions, and reflects the importance of immigrants as carriers of the diseas $\mathrm{e}^{10}$. In our country some regions are more affected than others, but the whole country is considered endemic for the disease ${ }^{11}$. At Ribeirão Preto City, São Paulo State, Brazil, an estimated prevalence of 71.8 cases per 100.000 inhabitants was described ${ }^{1}$.

The clinical picture of NC is dominated by epileptic seizures, but a wide range of neurological symptoms can occur ${ }^{12-15}$. Epileptic seizures occur more often at the transitional stage of the cysts, but can also occur at the calcified stage, the so-called inactive form ${ }^{16-18}$. In a recent consensus proposing diagnostic criteria for NC, several images were emphasized and classified as absolute, major and minor criteria ${ }^{19}$. Neuroimaging is strongly applied in the diagnosis for NC, permitting visualization of the parasite in its different stages ${ }^{20-22}$. Examination of cerebrospinal fluid (CSF) may be a valuable diagnostic tool, providing sensitive information about the inflammatory process and activity of $\mathrm{NC}^{23-27}$. Recently, a methodology able to detect anti-Taenia antigens was developed, using highly purified antibodies against Taenia antigens, showing high sensibility and specificity ${ }^{28}$.

The purpose of this study is: (1) to determine concentration of anti-Taenia antigens in cerebrospinal fluid of patients with neurocysticercosis; (2) to establish its relationship with clinical activity of the disease and with classical variables of CSF.

\section{METHOD}

Between July 2002 and March 2003, 36 patients with definitive diagnosis of NC according to consensus diagnostic criteria ${ }^{19}$, were attended at the Outpatient Clinic of Infectious Diseases of the Neurological Clinics of the Hospital of the School of Medicine of University of São Paulo, and at the Outpatient Neurological Clinic of the Hospital of Taubaté, University of Taubaté. The study was developed according to ethical rules in research involving human beings practiced at the Hospital of the School of Medicine of University of São Paulo, and submitted to analysis and approval of the Ethical Comission for Research Projects Analysis of that Hospital, under the research protocol number 132/03, according to resolution number 196/96 from Health National Council.

Patients were included in this study after signing a consent declaration. Concerning age, 9 patients (25\%) were between 21 and 30 years old; 14 patients (38.8\%) were between 31 and 40 years old, while 10 patients $(27.7 \%)$ were between 41 and 50 years old. Only 3 patients $(8.3 \%)$ were older than 51 . Twenty three patients $(63.8 \%)$ were male. There was a predominance of white patients (30 patients, $83.3 \%$ ), against 6 negro pa- tients $(16.7 \%)$. Thirty patients $(83.3 \%)$ originated from São Paulo State, while 6 patients $(16.7 \%)$ came from the States of Minas Gerais and Bahia, three cases each.

Almost all patients (97.2\%) presented epilepsy. Patients were classified in six groups, as regards clinical presentation and its temporal occurrence: (a) epileptic form, symptomatic in the last twelve months - 17 patients (47.2\%); (b) epileptic form, asymptomatic in the last twelve months - 14 patients (38.9\%); (c) epilepsy plus increased intracranial pressure - 2 patients (5.5\%); (d) epilepsy plus cerebrovascular involvement - 1 patient (2.8\%); (e) epilepsy plus optic neuritis - 1 patient $(2.8 \%)$; $(f)$ headache plus psychic desorder - 1 patient (2.8\%). All the patients with epilepsy were receiving antiepileptic drugs, even those asymptomatic in the last twelve months.

As regards magnetic resonance imaging, patients exhibited at the time of inclusion in the study the following findings: (a) multiple cystic lesions with contrast enhancement in at least one of the lesions in 17 patients (47.3\%); (b) multiple cystic lesions with no definite contrast enhancement in one patient (2.8\%); (c) single cystic lesion with contrast enhancement in 6 patients $(16.6 \%)$; (d) multiple nodular lesions in 7 patients (19.4\%); (e) single nodular lesion in 3 patients ( $8.3 \%$ ); (f) multiple nodular lesions with hydrocephalus in one patient $(2.8 \%)$; (g) multiple parenchymal calcifications in one patient (2.8\%).

A CSF sample was collected by lumbar puncture in sitting position, in order to perform global leukocyte count, cytomorphological profile, biochemical tests (total protein content, adenosine-deaminase activity, protein electrophoresis), IgG class antibodies research for syphilis, toxoplasmosis and cysticercosis (complement fixation test, indirect immunofluorescence, passive hemaglutination and enzyme-linked immunosorbent assay), besides cysticercus antigen research.

Antigens were detected in CSF samples by enzyme-linked immunosorbent assay (ELISA) using polyclonal sera of rabbit anti-Taenia solium cysticerci and anti-Taenia crassiceps cysticerci vesicular fluid, as described by Pardini et al28.

A blood sample was also collected from all patients in order to perform a immunoblotting assay for cysticercosis.

\section{RESULTS}

CSF findings are shown at Table 1.

By comparing the clinical presentation of epileptic form with Taenia antigen detection, we observed a significant increase in the symptomatic group in the last twelve months as compared to the asymptomatic group (Tables 2 and 3).

By comparing the Taenia antigen detection with the classical variables of CSF we observed a significant relationship with eosinophilorraquia, but with no other variables, including presence of specific antibodies (Tables 4 and 5). 


\section{DISCUSSION}

$\mathrm{NC}$ is a disease with multiple clinical presentations ${ }^{12,13}$ and variable evolution profile largely depending on immunological features. The relationship between host and parasite is complex. Immune evasion mechanism, besides different levels of local immunodepression, allows a longer and pacific parasite survival within the central nervous system without producing significant inflammatory reaction ${ }^{9}$. Usually, clinical activity takes place when cyst degeneration begins. Often multiple cysts in different phases of evolution coexist in the same patient making clinical management more difficult.

Correct diagnosis per se is not sufficient to determine severity, adequate therapeutic regimen and prognosis. It is necessary to know whether the disease is active: (1) under image criteria (cysts without enhancement) and (2) under immunological and clinical criteria. While diagnostic procedures are quite developed, disease activity criteria are poor and based almost exclusively on neuroimaging $^{16,17}$. Besides specific anti-Taenia antibodies which may persist for long time in CSF, the detection of Taenia antigens may be related to the acute phase of the inflammatory activity. This inflammatory activity is closely related with NC clinical activity.

Patients included in this study present peculiar clinical picture, with an absolute preponderance of epileptic form, possibly due to the strict application of diagnostic criteria defined by the recent consensus on NC diagnosis ${ }^{19}$. These criteria for definitive diagnosis of NC virtually excluded all patients with non-epileptic clinical manifestations, including the most severe hypertensive forms. The patients here included were often without epileptic crisis in the last 12 months. A few patients had other neurological manifestations. Despite this bias, our patients match the age, gender and race distribution referred in the literature. It means that it is a representative population, what allows us to validate the results.

CSF examination shows classical variables for the diagnosis of NC known for several decades: pleocy-
Table 1. CSF in patients with NC.

\begin{tabular}{lcc}
\hline CSF & N & $\%$ \\
\hline Pleocytosis & 6 & 16.7 \\
Presence of neutrophils & 23 & 63.9 \\
Presence of eosinophils & 11 & 30.6 \\
Protein increase & 18 & 50.0 \\
Gamma globulin increase & 9 & 25.0 \\
Positive complement fixation reaction & 5 & 13.9 \\
Positive indirect immunofluorescent test & 24 & 66.7 \\
Positive hemagglutination test & 24 & 66.7 \\
Positive enzyme-linked immunosorbent assay & 27 & 75.0 \\
Positive antigen detection & 17 & 47.2 \\
\hline N, number of cases. & &
\end{tabular}

Table 2. Clinical activity of epileptic form in the last twelve months related to antigen detection.

\begin{tabular}{lcc}
\hline Clinical presentation and & $\mathrm{N}$ & $\%$ \\
Taenia antigens & 10 & 27.8 \\
\hline Symptomatic with antigen & 3 & 8.3 \\
Asymptomatic with antigen & 7 & 19.4 \\
Symptomatic without antigen & 11 & 30.6 \\
\hline Asymptomatic without antigen &
\end{tabular}

tosis, eosinophilorraquia and the presence of specific antibodies ${ }^{23-25}$. This last topic has become a very sensible and specific parameter for the diagnosis, thanks to new techniques introduced in the clinical practice, like the enzyme-linked immunosorbant assay and immunoblotting.

In this group of patients, pleocytosis occurred in $16.7 \%$ of the cases, eosinophilorraquia in $30.6 \%$ and presence of specific antibodies in $75 \%$ of the cases; the complete syndrome occurred in only five patients (13.9\%). Neutrophils were observed in $63.9 \%$ of the cases, and a high protein content in half of the patients. Nine patients $(25 \%)$ present-

Table 3. Clinical activity related to antigen detection in patients with NC.

\begin{tabular}{lcc}
\hline Variable & $p$ & $\mathrm{~S} / \mathrm{NS}$ \\
\hline Clinical activity (all patients) vs. antigen detected & 0.01 & $\mathrm{~S}$ \\
Epileptic seizures in the last twelve months $v$ s. antigen detected & 0.02 & $\mathrm{~S}$ \\
\hline
\end{tabular}

$p$, associated probability; S, statistically significant value; NS, statistically not significant value. 
Table 4. Clinical variables of cerebrospinal fluid related to antigen detection: probability study.

\begin{tabular}{|c|c|c|}
\hline Variable & $p$ & S/NS \\
\hline Number of cells $x$ antigen & 0.052 & NS \\
\hline Neutrophils $\mathrm{x}$ antigen & 0.55 & NS \\
\hline Eosinophils $\mathrm{x}$ antigen & 0.006 & $\mathrm{~S}$ \\
\hline Increased protein content $x$ antigen & 0.74 & NS \\
\hline $\begin{array}{l}\text { Increased gamma globulin fraction } \mathrm{x} \\
\text { antigen }\end{array}$ & 0.18 & NS \\
\hline ELISA reactive $x$ antigen & 0.10 & NS \\
\hline
\end{tabular}

Table 5. Presence of antibodies (ELISA) related to antigen detection.

\begin{tabular}{lccc}
\hline Variable & $r$ & $p$ & S/NS \\
\hline $\begin{array}{l}\text { Reactive ELISA and antigen } \\
\text { (McNemar) }\end{array}$ & - & $\sim 0.80$ & NS \\
$\begin{array}{l}\text { Reactive ELISA and antigen } \\
\text { (regression analysis) }\end{array}$ & 0.30 & 0.08 & NS \\
\hline
\end{tabular}

$r$, Pearson correlation coefficient; $p$, associated probability; $S$, statistically significant value; NS, statistically not-significant value.

ed high levels of gamma globulins, but in only one with oligoclonal distribution. These results indicate the occurrence of non-cicatricial NC, with poor inflammatory reaction and immunorelease of specific antibodies.

Nowadays, the diagnosis for $\mathrm{NC}$ is greatly related to neuroimaging ${ }^{19}$. NC is one of the rare diseases where image morphology permits etiological diagnostic, as if we could see the parasite. Neuroimaging also permits follow-up of different phases of parasite, from the vesicular until the calcified stages $^{21,22}$. Nevertheless, neuroimaging information is morphological in nature, not functional. The data obtained from neuroimaging are not always proportional to the severity of the disease. Patients with multiple lesions may present asymptomatic, while patients with few images can be profoundly ill. Sotelo et al. ${ }^{18}$ tried to establish clinical activity criteria in order not to treat cicatricial forms of the disease, and predominantly morphological criteria have been adopted. Since then, presence of intact cysts in the brain parenchyma has been a frequent reference to "active forms of NC". Such reference does not seem reasonable, since inflammatory activity and clinical manifestations are absent at that time.
The concept of disease activity in patients with the NC diagnosis is relevant, and is not yet well established. Discrepancies between clinical presentation and image often turn therapeutic decisions difficult. There are no criteria to confirm whether the disease, rather than the image, is active or not.

In the most severe forms of NC, pleocytosis with presence of eosinophils in the CSF is one of the activity criteria related to cyst rupture and consequent antigen release at the nervous system. If we admit that antigen release is related to inflammatory activity, and that inflammatory activity is related to the clinical activity of the disease, we can test the hypothesis that Taenia antigen detection with inflammatory activity in the CSF is correlated with NC immunological active phase.

Taenia antigen was detected in part of the patients $(47.2 \%)$, all of them with definitive NC. It excludes the universality of the phenomenon. There is a non- casual statistic relationship between Taenia antigen and the occurrence of clinically active NC ( $p=0.02$ ) among patients with the epileptic form. So, it can be considered a clinical activity marker of the disease, at least in the epileptic form.

Taenia antigen detection was not statistically related to: (1) pleocytosis; (2) presence of neutrophils; (3) elevated protein content; (4) elevated gamma globulin fraction; (5) presence of specific antiTaenia antibodies (ELISA). These tests did not show concordance with antigen dosage related to its frequency (McNemar test) neither to the quantitative variation (regression tests). Nevertheless, the presence of eosinophils is related in a significant way to the occurrence of Taenia antigen $(p=0.006)$. These two determinations must translate the same phenomenon but eosinophilorraquia is significantly less sensitive.

We conclude that, in epileptic form of NC, Taenia antigen dosage may be able to give suitable information about disease activity, in a more sensitive way than any other classical variable of CSF.

\section{REFERENCES}

1. Takayanagui OM. Prevenção da neurocisticercose (CD ROM - Curso Pré-Congresso XX Congresso Brasileiro de Neurologia - setembro / 2002 Florianópolis, SC).

2. White AC Jr. Neurocysticercosis: update on epidemiology, pathogenesis, diagnosis and management. Ann Rev Med 2000;51:187-206.

3. Schantz PM, Cruz M, Sarti E, Pawlowski Z. Potential eradicability of taeniasis and cysticercosis. Bull Pan Am Health Organ 1993;27:397-403.

4. Román G, Sotelo J, Del Brutto O, et al. A proposal to declare neurocysticercosis an international reportable disease. Bull World Health Organ 2000;78:399-403. 
5. Del Brutto OH, Santibañez R, Noboa CA, Aguirre R, Diaz E, Alarcón TA. Epilepsy due to neurocysticercosis: analysis of 203 patients. Neurology 1992;42:389-392.

6. Manreza MLG. Epilepsia e neurocisticercose. In Guerreiro CAM, Guerreiro MM, Cendes F, Lopes-Cendes I (eds). Epilepsia. São Paulo: Lemos Editorial, 2000:255-264.

7. Bittencourt PRM, Adamolekum B, Bharucha N, et al. Epilepsy in the tropics: I. Epidemiology, socioeconomic risk factors, and etiology. Epilepsia 1996;37:1121-1127.

8. Shandera WX, White AC Jr, Chen JC, Diaz P, Armstrong R. Neurocysticercosis in Houston, Texas: a report of 112 cases. Medicine 1994;73: 37-52.

9. Carpio A. Neurocysticercosis: an update. Lancet Infect Dis 2002;2:751-762.

10. Schantz PM, Moore AC, Muñoz JL, et al. Neurocysticercosis in an orthodox Jewish community in New York City. N Engl J Med 1992;327:692-695.

11. Agapejev S. Epidemiologia e importância do estudo da neurocisticercose em nosso meio (CD ROM - Curso Pré-Congresso XX Congresso Brasileiro de Neurologia - setembro/2002, Florianópolis, SC).

12. Wittig EO. Neurocisticercose: formas clínicas e aspectos anátomopatológicos. In Machado LR, Livramento JA, Spina-França A, Nóbrega JPS (eds). Neuroinfecção 96. São Paulo: Clínica Neurológica HC / FMUSP, 1996:193-204.

13. Takayanagui OM, Jardim E. Aspectos clínicos da neurocisticercose: análise de 500 casos. Arq Neuropsiquiatr 1983;41:50-63.

14. Barinagarrementeria F, Cantú C. Frequency of cerebral arteritis in subarachnoid cysticercosis: an angiographic study. Stroke 1998;29:123-125.

15. Coelho CMF. Neurocisticercose: crises epilépticas, neuroimagem e líquido cefalorraqueano; estudo de 62 casos. Tese (doutorado) Universidade de São Paulo. São Paulo, 2002

16. Carpio A, Placencia M, Santillán F, Escobar A. A proposal for classification of neurocysticercosis. Can J Neurol Sci 1994;21:43-47.

17. Salgado P, Rojas R, Sotelo J. Cysticercosis: Clinical classification based on imaging studies. Arch Intern Med 1997;157:1991-1997.
18. Sotelo J, Guerrero J, Rubio F. A new classification based on active and inactive forms. Arch Intern Med 1988;148:442-445.

19. Del Brutto $\mathrm{OH}$, Rajshektar V, White AC Jr, et al. Proposed diagnostic criteria for neurocysticercosis. Neurology 2001;57:177-183.

20. Machado LR, Nóbrega JPS, Barros NG, Livramento J A, Baccheschi LA Spina-França A. Computed tomography in neurocysticercosis: a 10-year long evolution analysis of 100 patients with an appraisal of a new classification. Arq Neuropsiquiatr 1990;48:414-418.

21. Kramer LD, Locke GE, Byrd SE, Daryabagi J. Cerebral cysticercosis: documentation of natural history with CT. Radiology 1989;171:459-462.

22. Dumas JL, Visy JM, Belin C, Gaston A, Goldlust D, Dumas M. Parenchymal neurocysticercosis: follow-up and staging by MRI. Neuroradiology 1997;39:12-18

23. Livramento JA, Machado LR, Spina-França A. Sinalização do líquido cefalorraqueano em doenças inflamatórias crônicas do sistema nervoso central. Arq Neuropsiquiatr 1986;44:351-358.

24. Machado LR. Líquido cefalorraqueano e neurocisticercose: aspectos evolutivos da resposta inflamatória celular. Arq Neuropsiquiatr 1987;45:353-363.

25. Spina-França A, Livramento J A, Machado LR. Cysticercosis of central nervous system and CSF: immunodiagnosis of 1573 patients in 63 years (1929-1992). Arq Neuropsiquiatr 1993;51:16-20.

26. Bueno EC. Diagnóstico imunológico da neurocisticercose (CD ROM Curso Pré-Congresso XX Congresso Brasileiro de Neurologia - setembro/2002, Florianópolis, SC).

27. Bueno EC, Vaz AJ, Machado LR, Livramento JA, Mielli SR. Specific Taenia crassiceps and Taenia solium antigenic peptides for neurocysticercosis immunodiagnosis using serum samples. J Clin Microbiol 2000;38:146-151

28. Pardini AX, Vaz AJ, Machado LR, Livramento JA. Cysticercus antigens in CSF samples from patients with neurocysticercosis. J Clin Microbiol 2001;39:3368-3372. 